\title{
HUMAN PARVOVIRUS B19 INFECTIONS AMONG EXANTHEMATIC DISEASES NOTIFIED AS MEASLES
}

\author{
Rita C.N. Cubel, Marilda M. Siqueira, Elisabete O. Santos, Maria F. Pires, \\ Célia M. F. Cruz and Jussara P. Nascimento
}

\begin{abstract}
A total of 1397 sera collected from 1095 cases of exanthematic disease notified as measles in ES and RJ states during July 1992 to December 1994 were investigated. These sera were first tested for measles and rubella specific IgM. When they proved negative, they were tested for B19 specific IgM by an enzyme immunoassay. B19 infection was confirmed in 27 (2.5\%) of these cases. Sera from 194 negative cases for measles and rubella IgM received from other Brazilian states were also investigated and B19 infection was confirmed for 11 of them. Sera from these 38 IgM positive cases for B19, were tested for anti-B19 IgG by an enzyme immunoassay and for B19 DNA by dot blot bybridization. Anti-B19 IgG antibodies were detected in most of the acute sera. B19 DNA was detected in the acute serum of one patient that had been splenectomized before. As the exanthem caused by human parvovirus infection may be clinically diagnosed as rubella, it could be important to diagnose B19 infection in Brazil since it is becoming prevalent as the cause of rash in countries where rubella is controlled by vaccination.
\end{abstract}

Key-words: Human parvovirus B19. Exanthematic disease. Measles. Rubella.

Parvovirus B19, first described as a chance finding in the serum of healthy blood donors ${ }^{8}$. is now known to cause a spectrum of disease in humans. The most common clinical presentation of B19 infection is the childhood exanthem, erythema infectiosum (fifth disease). This classically begins with a facial rash (slapped cheek) that spreads to the trunk and limbs where it takes on a reticulate or lace-like appearance ${ }^{320}$. However the exanthem is highly variable, and may be misdiagnosed as rubella if laboratory investigation is not performed ${ }^{22}$. In Rio de Janeiro State, rubella and measles notifications are higher during the second half of the year ${ }^{521}$. B19 infections were also reported in Rio de Janeiro for the same period ${ }^{1011}$.

Departamento de Virologia da Fundação Oswaldo Cruz, Rio de Janeiro e Departamento de Microbiologia e Parasitologia da Universidade Federal Fluminense, Niterói, RJ, Laboratórios Regionais de Referência de Sarampo do Instituto Evandro Chagas, Belém, PA, Instituto de Saúde do Distrito Federal, Brasília, DF e Laboratório Central do Paraná, Curitiba, PR.

This work was partially supported by grants from COLAB/FNS, FAPERJ and CNPq, Brazil.

Address to: Dr ${ }^{a}$ Rita C.N. Cubel. Departamento de Virologia/IOC/FIOCRUZ. Av. Brasil 4365, Manguinhos, 21045-900 Rio de Janeiro, RJ, Brasil. Fax: 005521 270-6397. Recebido para publicação em 17/01/96.
Since the National Measles Vaccination Campaign in Brazil, during which all children under 14 years old were vaccinated against measles (April to May, 1992), all patients presenting with rash, high fever, and at least one of the following symptoms: cough, coryza or conjunctivitis, should be investigated for evidence of measles infection ${ }^{5}$.

In this study all patients had initially been investigated for evidence of measles by detection of measles specific IgM. If this proved negative, their stored sera were tested for the presence of rubella specific IgM. As B19 virus has also been shown to cause exanthematic disease, we used all the negative sera for measles and rubella IgM, to search for evidence of recent human parvovirus B19 and study the occurrence of fifth disease in the states of Espírito Santo and Rio de Janeiro, Brazil.

\section{MATERIAL AND METHODS}

Patient's sera. Blood was taken by veinepuncture from cases notified as measles by health workers from the epidemiological surveillance in the States of Espírito Santo (ES) and Rio de Janeiro (RJ) for a 2 1/2-year period. The patient's sera had all been stored at $-20^{\circ} \mathrm{C}$ until tested. Both acute and convalescent sera 
Cubel RCN, Siqueira MM, Santos EO, Pires MF, Cruz CMF, Nascimento JP. Human parvovirus B19 infections among exanthematic diseases notified as measles. Revista da Sociedade Brasileira de Medicina Tropical 30:15-20, jan-fev, 1997.

were investigated if available. A total of 1397 sera collected from 1095 patients were examined for the occurrence of measles, rubella and B19 infection. Sporadic sera from 194 cases negative for measles and rubella IgM were also received from another Brazilian states (Alagoas, Bahia, Ceará, Distrito Fedral, Pará, Paraíba, Paraná, Pernambuco, Rio Grande do Norte and Rondônia). These cases were to search only for B19 infection.

Diagnosis of recent measles and rubella infection. Specific IgM detection of measles and rubella was done by using the commercial assays available at all laboratories that participate of Measles Control Program in Brazil: Enzygnost anti-measles IgM (HoechstBehring) for measles; and Rubenostika IgM (Organon Teknika BV) for rubella.

Diagnosis of buman parvovirus B19 infection. Detection of specific anti-B19 IgM: All sera negative for measles and rubella IgM were tested for human parvovirus B19 specific IgM by an "in house" IgM capture enzyme immunoassay (MACEIA), as described previously". For this test, serum containing 100, 33, 10, 3.3, 1.0 and 0.33 radioimmunoassay (RIA) arbritary units (a.u.) of B19 IgM and normal human serum were used as positive and negative controls. Sera containing $\mathrm{P} / \mathrm{N}$ values equal or greater than that one obtained with the 10 RIA a.u. control serum were considered as positive.

Detection of specific anti-B19 IgG: All antiB19 IgM positive cases were tested for the presence of anti-B19 IgG antibodies by an "in house" enzyme immunoassay using recombinant B19 capsids produced in insect cells (Sf9) as antigen ${ }^{6}$. Briefly, flat bottomed microtiter plates (Immulon 2, Dynatech) were coated with $50 \mu 1$ of recombinant B19 capsids ( $1 \mu \mathrm{g} / \mathrm{ml}$; MedImmune Inc., USA) or 4\% of SF9 cells diluted 1:1000 in $0.05 \mathrm{M}$ carbonate buffer ( $\mathrm{pH}$ 9.6) and the plates were incubated for $1.5 \mathrm{~h}$ at $37^{\circ} \mathrm{C}$. The plates were washed three times with PBS ( $\mathrm{pH}$ 7.2) containing $0.05 \%$ Tween 20 (PBST), then $200 \mu \mathrm{l}$ of blocking buffer (PBS pH 7.2 plus $0.1 \%$ bovine serum albumine) was added, and the microtiter plates incubated for $1.5 \mathrm{~h}$ at $37^{\circ} \mathrm{C}$. After washing the plates, $50 \mu \mathrm{l}$ of patient serum diluted 1:20 in diluent buffer (blocking buffer plus $0.5 \%$ Tween 20) was added to wells in duplicate and the plates incubated for $1.5 \mathrm{~h}$ at $37^{\circ} \mathrm{C}$. After the wells were washed, $50 \mu \mathrm{l}$ of peroxidase-conjugate goat anti-human $\mathrm{IgG}$ (Sigma) diluted 1:20,000 in diluent buffer was added, and the plates incubated for $1 \mathrm{~h}$ at $37^{\circ} \mathrm{C}$. Finally, the plates were washed five times and incubated in the dark at room temperature with $100 \mu$ l of substrate solution (tetramethylbenzidine in phosphate-citrate buffer). The reaction was stopped by the addition of $100 \mu \mathrm{l}$ of $2 \mathrm{M} \mathrm{H}_{2} \mathrm{SO}_{4}$, and the absorbance at $450 \mathrm{~nm}$ was measured with a Titertek Multiscan Plus spectrophotometer. Positive and negative B19 IgG sera were used as controls. The absorbance values obtained in the wells with the recombinant antigen $(\mathrm{P})$ were compared to that one with the insect cells $(\mathrm{N})$. Sera were considered as positive when $\mathrm{P} / \mathrm{N}$ values were greater than 2.0 and the $\mathrm{P}$ - N values were greater than 0.10.

Detection of B19 DNA: All anti-B19 IgM positive cases were also tested for the presence of B19 DNA by "dot-blot" hybridization assay using a biotin-labelled probe $^{17}$.

\section{RESULTS}

Sera were obtained from 1095 measles notified cases in RJ and ES States during July 1992 to December 1994, and tested for measles specific IgM. Measles infection was confirmed in only $52(4.7 \%)$ cases (Table 1$)$. About $40 \%$ of the cases were due to rubella infection, and relatively few B19 infections (27 cases - 2.5\%)

Table 1 - Laboratory diagnosis among measles notified cases in Rio de Janeiro (RJ) and Espírito Santo (ES) States

\begin{tabular}{|c|c|c|c|c|c|c|c|c|c|c|}
\hline \multirow{3}{*}{ State } & \multirow{3}{*}{ Year } & \multicolumn{6}{|c|}{ IgM positive } & \multirow{2}{*}{\multicolumn{2}{|c|}{$\begin{array}{l}\text { IgM negative } \\
\text { (all three) }\end{array}$}} & \multirow{3}{*}{ Total } \\
\hline & & \multicolumn{2}{|c|}{ Measles } & \multicolumn{2}{|c|}{ Rubella } & \multicolumn{2}{|c|}{ B19 } & & & \\
\hline & & $\mathrm{n}^{\mathrm{o}}$ & $\%^{*}$ & $\mathrm{n}^{\mathrm{o}}$ & $\%$ & $\mathrm{n}^{\mathrm{o}}$ & $\%$ & $\mathrm{n}^{\mathrm{o}}$ & $\%$ & \\
\hline \multirow{3}{*}{ RJ } & 1992 & 29 & 9.6 & 131 & 43.4 & 4 & 1.3 & 138 & 45.7 & 302 \\
\hline & 1993 & 13 & 3.3 & 168 & 43.2 & 5 & 1.3 & 203 & 52.2 & 389 \\
\hline & 1994 & 2 & 1.1 & 74 & 42.3 & 11 & 6.3 & 88 & 50.3 & 175 \\
\hline \multirow{3}{*}{ ES } & 1992 & 3 & 4.6 & 25 & 38.5 & 3 & 4.6 & 34 & 52.3 & 65 \\
\hline & 1993 & 4 & 2.9 & 71 & 51.8 & 3 & 2.2 & 59 & 43.1 & 137 \\
\hline & 1994 & 1 & 3.7 & 7 & 25.9 & 1 & 3.7 & 18 & 66.7 & 27 \\
\hline Total & & 52 & 4.7 & 476 & 43.5 & 27 & 2.5 & 540 & 49.3 & 1095 \\
\hline
\end{tabular}

* Percentage from the total number of cases. 
Cubel RCN, Siqueira MM, Santos EO, Pires MF, Cruz CMF, Nascimento JP. Human parvovirus B19 infections among exanthematic diseases notified as measles. Revista da Sociedade Brasileira de Medicina Tropical 30:15-20, jan-fev, 1997.

were identified. However, among the cases received from ES, almost the same number of positives for measles and B19 infection were obtained. For RJ, during the period studied there was an increase in the incidence of B19 infection, while the number of cases due to measles infection was decreasing.

The seasonal distribution of B19 and rubella cases in ES and RJ States was examined (Figures 1 and 2). Rubella and B19 infection had a peak occurrence in the second half of the year, late winter and spring time; with sporadic cases of B19 and rubella during the first half of the year.
A total of 301 sera from 194 cases negative for measles and rubella $\operatorname{IgM}$ were obtained from other Brazilian states and investigated for B19 IgM. Twenty six cases were received from Pará (north Brazil) in the year of 1989 and B19 IgM could be detected in 5 (19.2\%) cases. Among 47 cases from Paraná (south Brazil) in 1993, B19 infection was confirmed for 5 $(10.6 \%)$ of these cases while for Distrito Federal we found only one positive (2.6\%) in 38 cases in 1992.

From the 38 cases IgM positive for B19, for 19 of them acute and convalescent sera were available (Table 2). From 38 sera collected from

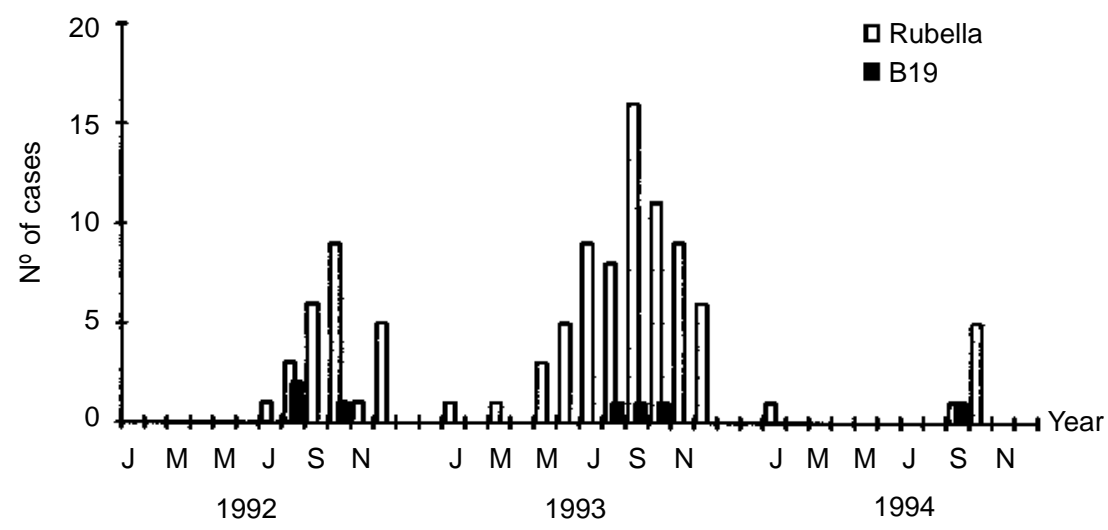

Figure 1 - Seasonal distribution of B19 and rubella cases in ES State.

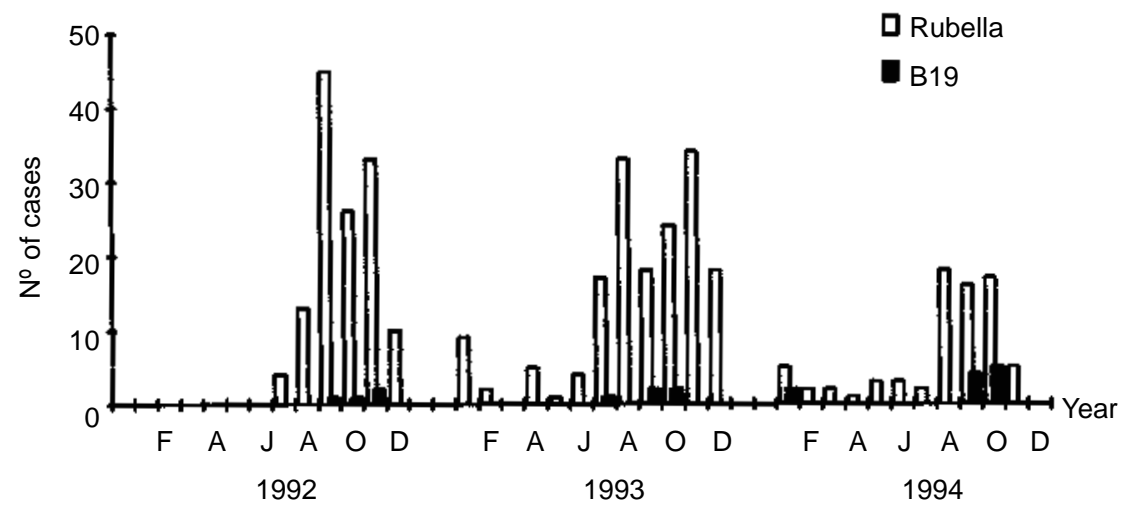

Figure 2 - Seasonal distribution of B19 and rubella cases in RJ State. 
Cubel RCN, Siqueira MM, Santos EO, Pires MF, Cruz CMF, Nascimento JP. Human parvovirus B19 infections among exanthematic diseases notified as measles. Revista da Sociedade Brasileira de Medicina Tropical 30:15-20, jan-fev, 1997.

acute phase only two of them were negative for B19 IgM. B19 DNA could be detected in one of these IgM negative sera by dot blot hybridization. For this patient $\operatorname{IgM}$ and $\operatorname{IgG}$ was present only in the convalescent serum. B19 IgG was detected in 31 of the 35 acute sera tested and all but one convalescent sera was positive for B19 IgG. IgM and IgG antibodies for B19 virus could be detected in sera collected from 1 to 22 days after the beginning of the rash.

Table 2 - Anti - B19 IgG antibodies and B19 DNA testing for B19 IgM positive cases.

\begin{tabular}{|c|c|c|c|c|c|c|c|}
\hline & \multicolumn{2}{|c|}{ B19 IgM } & \multicolumn{2}{|c|}{ B19 IgG } & \multirow{2}{*}{\multicolumn{2}{|c|}{$\begin{array}{c}\text { B19 DNA } \\
(+)(-)\end{array}$}} & \multirow[t]{2}{*}{ Total } \\
\hline & $(+)$ & $(-)$ & $(+)$ & $(-)$ & & & \\
\hline Only acute serum & 19 & 0 & 18 & 1 & 0 & 19 & 19 \\
\hline Acute and & 17 & 2 & $13^{*}$ & 3 & $1^{\text {*a* }}$ & 18 & 19 \\
\hline convalescent sera & 15 & 4 & 14 & 1 & 0 & 19 & 19 \\
\hline Total & 51 & 6 & 45 & 5 & 1 & 56 & 57 \\
\hline
\end{tabular}

* For Pará acute sera from 3 patients and 4 convalescent sera were not available for IgG test.

*** Acute serum from this patient was $\operatorname{IgM}$ and $\operatorname{IgG}$ negative. Convalescent sera was IgM and IgG positive.

\section{DISCUSSION}

Since the first association made by Anderson e cols ${ }^{4}$ of an outbreak of erythema infectiosum (EI) and B19 infection many other reports have appeared and parvovirus B19 is now known to be the etiological agent of $\mathrm{EI}^{18} 20$.

The first description of EI with laboratory confirmation in Brazil was done during 1987 in Belém, $\mathrm{PA}^{12}$. Althought anti-B19 IgM detection was possible only for three patients, similar clinical findings were reported for ten other cases during a four - year period, 1984 to $1987^{16}$. Most of these cases occurred during the first half of the year (January to June). During the following years (1988 to 1989) twenty-two laboratory confirmed cases were reported in Belém ${ }^{14}$. Another report from the same area for 1989 to 1990 found just one positive case out of $42^{13}$.

We are now reporting $27(2.5 \%)$ anti-B19 IgM positive cases among 1095 cases reported as measles in RJ and ES states during the years 1992 to 1994. Shirley e cols ${ }^{22}$ detected B19 IgM positive sera in $6.8 \%$ of 627 cases of rubella like-illness in the West Midlands, UK, also during a $21 / 2$ - year period (1983 to 1985). The proportion of positive cases found in RJ and ES States is lower and this can be easily explained because EI is clinically more similar to rubella than to measles. In the West Midlands study the percentage varied from 3\% to 19\% for different years, and probably 1985 was an epidemic year for B19 in the UK ${ }^{1}$. In our present study we probably lose an epidemic period.

It is difficult to discuss the results found for another Brazilian states because only for ES and RJ states a follow-up for a $21 / 2$ - year period to investigate the occurrence of measles, rubella and B19 infections was done.

Our results for etiology of exanthematic disease in RJ and ES clearly show the impact of measles mass vaccination over the measles virus circulation in both States. From the 92 cases received from ES in the years of 1992 and 1994, we had the same number of positives for measles and B19. In a previous study of an outbreak of exanthem in Niterói, RJ during 1991 we obtained $80 \%$ of laboratory confirmation of 112 measles reported cases ${ }^{19}$. In that study no cases with anti-B19 IgM were found and rubella was diagnosed in only four cases.

Diagnosis of erythema infectiosum is mainly based on serology, because specific antibodies are present at the onset of the symptoms. At this time, in normal individuals viraemia can no more be detected ${ }^{2}$. We were able to detect B19 DNA in a patient with rash. This patient had been splenectomized before and it may have contributed to the longer viraemia. Prolonged viraemia has been described to occur when immunocompromised patients are infected with B19²3.

In our study no relationship between days of disease and antibody-detection could be observed, since IgM and, in most cases, IgG were present after one day of the onset of the rash.

In about $50 \%$ of the cases the etiology of the rash was unknown. It is well known that erythematous rashes occur in many common viral infections, like arboviruses, infectious mononucleosis, enteroviruses and the more recently described human herpesvirus 6 (HHV-6). Preliminary studies of HHV-6 infection in north-east Brazil detected seroprevalence rates of $70 \%$ and children were found to possess high level of antibodies ${ }^{15}$. So the etiology of these cases remains to be elucidated.

Amplify this study would be desirable as also to consider B19 infection as an alternative diagnosis to rubella especially during pregnancy in which B19 virus can cross the placenta and 
Cubel RCN, Siqueira MM, Santos EO, Pires MF, Cruz CMF, Nascimento JP. Human parvovirus B19 infections among exanthematic diseases notified as measles. Revista da Sociedade Brasileira de Medicina Tropical 30:15-20, jan-fev, 1997.

harms the fetus. Human parvovirus B19 infection is clinically indistinguishable from rubella ${ }^{22}$ and is becoming prevalent as the cause of rash in countries where rubella is controlled by vaccination? ${ }^{7}$. It could be particularly important to diagnose B19 infections in Brazilian states like Distrito Federal, Paraná and São Paulo, in which rubella vaccination programs are in progress.

\section{RESUMO}

Um total de 1397 soros colbidos de 1095 casos de exantema notificados como sarampo, nos estados do ES e RJ, no periodo de julbo de 1992 a dezembro de 1994, foram investigados. Estes soros foram inicialmente testados para sarampo e rubéola por detecção de IgM específica. Os casos negativos foram então testados para a presença de IgM específca anti-B19 por um ensaio imunoenzimático. A infecção pelo B19 foi confirmada em 27 (2,5\%) destes casos. Soros de 194 casos negativos para sarampo e rubéola provenientes de outros estados brasileiros foram também investigados, e a infecção pelo B19 pode ser confirmada em 11 destes casos. Os soros dos 38 casos IgM positivos para B19 foram testados para a presença de IgG específica anti-B19 por um ensaio imunoenzimático, e para a presença do ADN viral por hibridização em "dots" (dot blot). IgG específica anti-B19 pode ser detectada na maioria dos soros de fase aguda, e o ADN viral foi detectado no soro de fase aguda de um paciente esplenectomizado. Como o exantema causado pela infecção pelo parvovírus bumano pode ser clinicamente diagnosticado como rubéola, seria importante realizar o diagnóstico desta virose no Brasil, já que um aumento no número de casos de exantema por $B 19$ tem sido relatado nos países onde a rubéola é controlada por vacinação.

Palavras-chaves: Parvovírus Humano B19. Doença Exantemática. Sarampo. Rubéola.

\section{ACKNOWLEDGEMENTS}

This work would not be possible without the aid of the responsibles for Measles Surveillance in the states of Rio de Janeiro (Marcia Mello) and Espírito Santo (Alexandra M Ferreira). The authors wish to thank Ana CR Alferes, Monica N Mazorche, Verônica CR Soares and Zélia PA Ferro for technical support. RCN Cubel received a CNPq fellowship as part of her PhD studies at the Instituto de Microbiologia, Universidade Federal do Rio de Janeiro. The authors also wish to thank Dr. Kevin E Brown
(Hematology Branch, NIH, USA) for critical reading of the manuscript.

\section{REFERENCES}

1. Anderson MJ, Cohen BJ. Human parvovirus B19 infections in United Kingdom 1984-86. Lancet 1:738-739, 1987.

2. Anderson MJ, Higgins PG, Davis LR, Willman JS, Jones SE, Kidd IM, Pattison JR, Tyrrell DA. Experimental parvoviral infection in humans. Journal of Infectious Diseases 152:257-265, 1985.

3. Anderson MJ, Jones SE, Fisher-Hoch SP, Lewis E, Hall SM, Bartlett CR, Cohen BJ, Mortimer PP, Pereira MS. The human parvovirus, the cause of erythema infectiosum (fifth disease)? [letter] Lancet 1:1378, 1983.

4. Anderson MJ, Lewis E, Kidd IM, Hall SM, Cohen BJ. An outbreak of erythema infectiosum associated with human parvovirus infection. Journal of Hygiene 93: 85-93, 1984.

5. Anonymous. Capacitacão de pessoal para a vigilância epidemiológica do sarampo. Módulo Instrucional I FNS/MS/Brasil p.1-77, 1992.

6. Bansal GP, Hatfield JA, Dunn FE, Kramer AA, Brady F, Riggin CH, Collett MS, Yoshimoto K, Kajigaya S, Young NS. Candidate recombinant vaccine for human B19 parvovirus. Journal of Infectious Diseases 167:1034-1044, 1993.

7. Communicable Disease Surveillance Centre. Trends in rubella and parvovirus B19 infections. Communicable Disease Report 3:125, 1993.

8. Cossart YE, Field AM, Cant B, Widdows D. Parvovirus-like particles in human sera. Lancet 1 : 72-73, 1975.

9. Cubel RC, Alferes AC, Cohen BJ, Nascimento JP. Application to Immunoglobulin M Capture Hemadherence Assays of Hemagglutination of Monkey Erythrocytes by Native and Recombinat Human Parvovirus B19 Antigens. Journal of Clinical Microbiology 32:1997-1999, 1994.

10. Cubel RC, Garcia AG, Pegado CS, Ramos HI, Fonseca ME, Clewley JP, Cohen BJ, Nascimento JP. Human parvovirus B19 infection and hydrops fetalis in Rio de Janeiro. Memórias do Instituto Oswaldo Cruz 91: 147-151, 1996.

11. Cubel RC,Valadão MC, Pereira WV, Magalhães MC, Nascimento JP. Aplastic crisis due to human parvovirus B19 infection in hereditary hemolytic anaemia. Revista do Instituto de Medicina tropical de São Paulo 34:479-482, 1992. 
Cubel RCN, Siqueira MM, Santos EO, Pires MF, Cruz CMF, Nascimento JP. Human parvovirus B19 infections among exanthematic diseases notified as measles. Revista da Sociedade Brasileira de Medicina Tropical 30:15-20, jan-fev, 1997.

12. Freitas RB, Linhares AC, Miranda MF, Gabbay YB. Novo agente de doença exantemática na Amazônia: o parvovírus "B 19". Boletim Epidemiológico (Rio de Janeiro) 20:104, 1988.

13. Freitas RB, Miranda MF, Shirley J, Tudor R, Desselberger U, Linhares AC. Parvovirus B19 antibodies in sera of patients with unexplained exanthemata from Belém, Pará, Brazil. Memórias do Instituto Oswaldo Cruz 88:497-499, 1993.

14. Freitas RB, Wong D, Boswell F, Miranda MF, Linhares AC, Shirley J, Desselberger U. Prevalence of human parvovirus (B19) and rubellavirus infections in urban and remote rural areas in northern Brazil. Journal of Medical Virology 32:203-208, 1990.

15. Linhares MI, Eizuru Y, Tateno S, Minamishima Y. Seroprevalence of human herpesvirus- 6 infection in Brazilian and Japanese populations in the north-east of Brazil. Microbiology and Immunology 35:1023-1027, 1991.

16. Miranda MF, Linhares AC, Shirley JA. Fifth disease in children living in Belém, Brazil. Revista do Instituto de Medicina tropical de São Paulo 31:359-362, 1989.

17. Mori J, Field AJ, Clewley JP, Cohen BJ. Dot Blot hybridization assay of B19 virus DNA in clinical specimens. Journal of Clinical Microbiology 27:459-464, 1989.

18. Nunoue T, Okochi K, Mortimer P, Cohen BJ. Human parvovirus (B19) and erythema infectiosum. Journal of Paediatrics 107:38-40, 1985.

19. Oliveira SA, Siqueira MM, Costa AJ, Almeida MT, Nascimento JP. Serological findings during a measles outbreak occuring in a population with a high vaccination coverage. Revista do Instituto de Medicina tropical de São Paulo 37:421-425, 1995.

20. Plummer FA, Hammond GW, Forward K, Sekla L, Thompson LM, Jones SE, Kidd IM, Anderson MJ. An erythema infectiosum-like illness caused by human parvovirus infection. New England Journal of Medicine 313:74-79, 1985.

21. Schatzmayr HG. Aspects of rubella infection in Brazil. Reviews of Infectious Diseases 7 (suppl 1): S53-S55, 1985.

22. Shirley JA, Revill S, Cohen BJ, Buckley MM. Serological study of rubella-like illnesses. Journal of Medical Virology 21:369-379, 1987.

23. Young NS. Hematologic and hematopoietic consequences of B19 parvovirus infection. Seminars in Hematology 25:159-172, 1988. 